学術論文

\title{
振れ補正用三自由度アクチュエータの動的モデリング
}

\section{Dynamic Modeling of Three-Degree-of-Freedom Actuator for Image Stabilization}

\author{
部矢 明 ${ }^{* 1}$ (学生員), 平田 勝弘 ${ }^{* 1}$ (正員), 新口 昇 ${ }^{* 1}$ (正員), \\ 吉元 崇倫 ${ }^{* 2}$, 太田 智浩*2
}

Akira HEYA (Stu. Mem), Katsuhiro HIRATA (Mem.), Noboru NIGUCHI (Mem.), Takamichi YOSHIMOTO, Tomohiro OTA

\begin{abstract}
Recently, image quality deteriorations due to vibrations have become a problem in an autonomous system. A lens-unit swing system which consists of a lens and an imaging device is a kind of image stabilization technologies that generate an inverse motion against camera shakes. This system can correct an image from camera shakes over wide rotation ranges around three axes. However, this system has some problems such as an increase in size and weight. In order to solve these problems, we proposed a novel three-degree-of-freedom actuator for image stabilization. In this paper, we create a dynamic model for the actuator. The motion equation and state equation are derived by Lagrangian method. The validity of the dynamic model is investigated by the comparison of dynamic analyses using 3-D finite element method. In addition, the optimal servo system is designed using the dynamic model, and the effectiveness of the dynamic modeling method is verified.
\end{abstract}

Keywords: 3-degree-of-freedom actuator, image stabilization, electromagnetic actuator, 3-D finite element method.

(2017 年 10 月 26 日受付, 2017 年 12 月 29 日再受付, 2018 年 2 月 1 日再々受付)

\section{1 緒言}

災害調査，介護ロボット，ドローンシステム，自動 運転車等の自律システムにおいて周囲の環境の認識は 重要な課題であり，視覚によって得られる情報が大き な役割を果たす。これらのロボットやシステムでは, カメラによって移動しながら情報を取得しなければな らないだけでなく，実環境内で人のような高い空間認 識能力が求められる[1-3]。しかし，移動時に発生する 振れによる画質劣化に起因した認識精度の低下とサイ ズが問題となる。振れ補正方式の一つであるレンズユ ニットスイング方式は, レンズと撮像素子を一つのユ ニットとして振れ振動と逆相に駆動することで振れ補 正を行う[4]。本方式は, 三軸方向に広角で振れを補正 可能であるといら大きな利点を持つ。一方で, 複数の モータとリンクによりユニットを駆動させるためシス テムの大型化と重量の増加が課題となる。

そこで，複数のリンクを用いずに 1 台で三自由度駆 動可能な三自由度アクチュエータの振れ補正システム

\footnotetext{
連絡先： 部矢 明, 广565-0871 大阪府吹田市山田丘 2-1, 大阪大学大学院工学研究科知能・機能創成工学専攻, e-mail: akira.heya@ams.eng.osaka-u.ac.jp

${ }^{* 1}$ 大阪大学 *2 ペナソニック株式会社
}

への適用により, システムの小型化が期待できる[5-11] 筆者らはこれまで, 振れ補正システムへの適用を目 的とした小型かつ制御装置の簡素な三自由度アクチュ エータを提案し, 三次元有限要素法を用いた電磁場解 析と運動方程式の連成解析により，そのトルク特性と 制御性能の評価を行ってきた[12-13]。しかし，高速な 動作を評価する場合, タイムステップの細かい解析を 行う必要があり，解析時間の増加を招く。特に，三次 元有限要素法を用いた電磁場解析においてはタイムス テップと解析精度はトレードオフの関係となることが 一般的であり，十分な解析精度を得るためにタイムス テップを細かくするほど多くの解析時間を要す。

そこで本研究では，計算時間の短縮と状態方程式の 導出を目的とした動的モデリングを構築する。まずラ グランジュ法をもとに提案したアクチュエータの運動 方程式を導出した。次にトルク発生式，電気回路方程 式と運動方程式を連成し，モータの駆動特性を考慮し た状態方程式を導出した。そして，導出したシステム の時間応答と三次元有限要素法を用いた動解析の解析 結果を比較し, 導出したシステムの有効性を検証した。 加えて，導出した状態方程式を用いることで提案した アクチュエータに対して最適制御が適用可能であるこ とを示すため, 最適サーボシステムを設計し, 制御シ ステムの動特性を検証した。 


\section{2 アクチュエータ概要}

\section{1 基本構造と仕様}

振れ補正用三自由度アクチュエータの構成を Fig. 1 に示寸[13]。また, 本アクチュエータの可動子と固定子 の構造を Fig. 2 に示寸。内側の可動子は永久磁石とイ ンナーヨークから構成され, 外側の固定子はアウター ヨーク，Z 軸駆動用ヨークとコイルから構成される。 $\mathrm{X}$ 軸・ $\mathrm{Y}$ 軸駆動用コイルはアウターヨークに沿って巻 かれており，Z軸駆動用コイルは Z 駆動用ヨークに沿 って巻かれている。

アクティブな撮影環境に対応するため, 本アクチュ エータの振れ補正可能周波数の最大值は $100 \mathrm{~Hz}$ とし ている。また， $\mathrm{X}$ 軸・Y 軸まわりは最大 25 度， $\mathrm{Z}$ 軸ま わりは最大 5 度まで駆動可能である。各軸まわりのコ イル抵抗, インダクタンス, ターン数, トルク定数, ディテント定数を Table 1 に示す。ここで, トルク定数 はコイルに $1 \mathrm{~A}$ 印加時の電流トルクの平均值として算 出した。また, 数值モデル簡略化のために可動子角度 に対するディテントトルクの傾きをディテント定数と

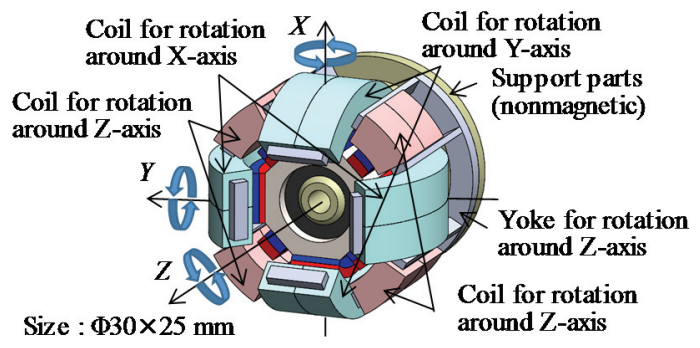

Fig. 1 Basic structure of the actuator.

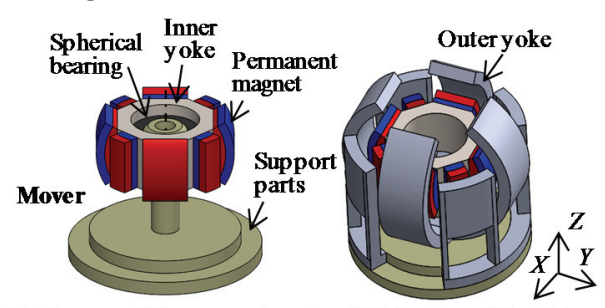

(a) Mover and the support parts (b) Mover and the stator

Fig. 2 Basic structure of the actuator.

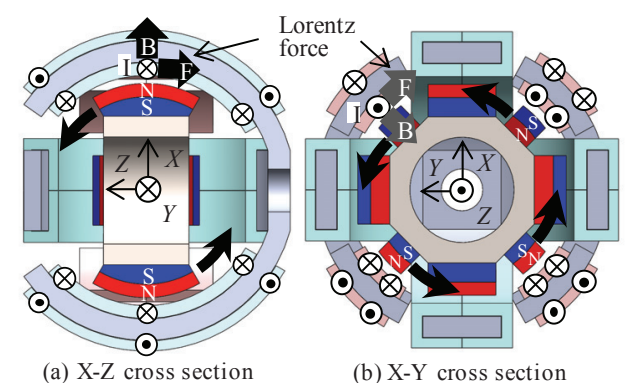

Fig. 3 Operation principle of the actuator.
して定義し，ディテントトルクの線形近似を行った [12]。なお，この線形近似はアクチュエータの駆動範囲 が狭いために成立するものである。

\section{2 駆動原理}

提案する三自由度アクチュエータの動作原理を Fig. 3 に示す。各軸駆動用コイルに電流を流すことでコイ ルはローレンツカを受け，その反力によって可動子に トルクが働き，駆動する。本アクチュエータの動作の 特徵は 2 つある。ず 1 つ目として， 3 相のみの制御 で三自由度駆動が可能であることが挙げられる。これ により, 従来の三自由度アクチュエータと比較して簡 易な制御装置で可動子の回転運動を制御できる。次に 2 つ目として，ディテントトルクが可動子を安定点に 引き込む役割を果たすことが挙げられる。これにより， 可動子を安定点に戻すための復帰機構が不要となり, アクチュエータの小型化に貢献する。

\section{3 動的モデリング}

本章では，三入力三出力システムである振れ補正用 三自由度アクチュエータの動的モデリングについて述 べる。まず可動子の姿勢表現を定め, トルク発生式, 回路方程式と運動方程式を連成し，モータの駆動特性 を考慮した状態方程式を導出する。

\section{1 可動子の姿勢表現}

可動子姿勢を Fig. 4 に示す XYZ 系のオイラー角に より表現する。可動子座標系 $A_{M}$ から固定子座標系 $A_{S}$ 一の変換式と回転行列 $R$ は次のように表される。

$$
\begin{gathered}
A_{S}=R_{x}(\alpha) R_{y 1}(\beta) R_{z 2}(\gamma) A_{M} \\
R=\left[\begin{array}{ccc}
c \beta c \gamma & -c \beta s \gamma & s \beta \\
c \gamma \alpha \alpha s \beta+c \alpha s \gamma & c \alpha c \gamma-s \alpha s \beta s \gamma & -c \beta s \alpha \\
-c \alpha c \gamma \beta+s \alpha s \gamma & c \gamma s \alpha+c \alpha s \beta s \gamma & c \alpha c \beta
\end{array}\right]
\end{gathered}
$$

ただし， $\mathrm{s} \alpha=\sin \alpha ， \mathrm{c} \alpha=\cos \alpha$ という略記法を用いてお り， $\beta, \gamma$ についても同様な記号を用いることとする。

Table 1. Specifications of the actuator.

\begin{tabular}{cccc}
\hline \hline Symbol & Parameter & X/Y-axis & Z-axis \\
\hline$R_{c}$ & Coil resistance $[\Omega]$ & 4.8 & 39.7 \\
$L$ & Coil inductance $[\mathrm{H}]$ & $1.1 \times 10^{-2}$ & $2.2 \times 10^{-2}$ \\
$N_{\text {coil }}$ & Number of turns of coil & 800 & 1200 \\
$K_{T}$ & Torque constant $[\mathrm{Nm} / \mathrm{A}]$ & $1.3 \times 10^{-2}$ & $3.7 \times 10^{-2}$ \\
$K_{D}$ & Detent constant $[\mathrm{Nm} / \mathrm{rad}]$ & $9.2 \times 10^{-3}$ & $5.7 \times 10^{-2}$ \\
\hline \hline
\end{tabular}




\section{2 運動方程式の導出}

振れ補正用三自由度アクチュエータの運動方程式 をラグランジュ法に基づき導出した。一般化座標 $q \in$ $\mathbb{R}^{m}$ としたラグランジュの運動方程式は次のように表 される。

$$
\frac{d}{d t} \frac{\partial L}{\partial \dot{q}_{i}}-\frac{\partial L}{\partial \dot{q}_{i}}=\tau_{i}(i=1,2, \ldots, m)
$$

また, 式(3)におけるラグランジュ関数 $L(q, \dot{q})$ は次の ように表される。

$$
L(q, \dot{q})=K(q, \dot{q})-P(q)
$$

そして, 可動子の運動エネルギ $K(q, \dot{q})$ は次式で求め ることができる。

$$
K(q, \dot{q})=\frac{1}{2} \omega^{T} R^{T} \operatorname{IR} \omega
$$

ここで，角速度ベクトル $\omega$ と慣性テンソル I は次の ように表される。

$$
\begin{aligned}
& \omega=\left[\begin{array}{l}
1 \\
0 \\
0
\end{array}\right] \dot{\alpha}+\mathrm{R}_{\mathrm{x}}(\alpha)\left[\begin{array}{l}
0 \\
1 \\
0
\end{array}\right] \dot{\beta}+\mathrm{R}_{\mathrm{x}}(\alpha) \mathrm{R}_{\mathrm{y} 1}(\beta)\left[\begin{array}{l}
0 \\
0 \\
1
\end{array}\right] \dot{\gamma} \\
& =\left[\begin{array}{c}
\dot{\alpha}+\dot{\gamma} \mathrm{s} \beta \\
\dot{\beta} \mathrm{c} \alpha-\dot{\gamma} \mathrm{s} \alpha \\
\dot{\beta} \mathrm{c} \alpha+\dot{\gamma} \alpha \mathrm{c} \beta
\end{array}\right]
\end{aligned}
$$

$$
I=\operatorname{diag} \cdot\left[\begin{array}{lll}
I_{x x} & I_{y y} & I_{z z}
\end{array}\right]
$$

ここで, $I_{x x}=I_{y y}=I_{I}=4.3 \times 10^{-7} \mathrm{kgm}^{2}, I_{z z}=I_{3}=7.1 \times 10^{-7} \mathrm{kgm}^{2}$ である。さらに，可動子は球面軸受により支持される ため, 回転動作を行う際に質量中心の移動はないこと から, 位置エネルギは $P(q)=0$ となる。以上より, 本ア クチュエータの運動方程式は $q=[\alpha \beta \gamma]^{T}$ として式(3)を 解くことで次のようにまとめられる。

$$
\begin{gathered}
H \ddot{q}+C \dot{q}=\tau \\
H=\left[\begin{array}{ccc}
I_{1} c^{2} \beta+I_{3} s^{2} \beta & 0 & I_{3} s \beta \\
0 & I_{1} & 0 \\
I_{3} s \beta & 0 & I_{3}
\end{array}\right] \\
C=\left[\begin{array}{ccc}
2 \dot{\beta}\left(I_{3}-I_{1}\right) s \beta c \beta & \dot{\gamma} I_{3} c \beta & 0 \\
\dot{\alpha}\left(I_{1}-I_{3}\right) s \beta c \beta & 0 & -\dot{\alpha} I_{3} c \beta \\
\dot{\beta} I_{3} c \beta & 0 & 0
\end{array}\right]
\end{gathered}
$$

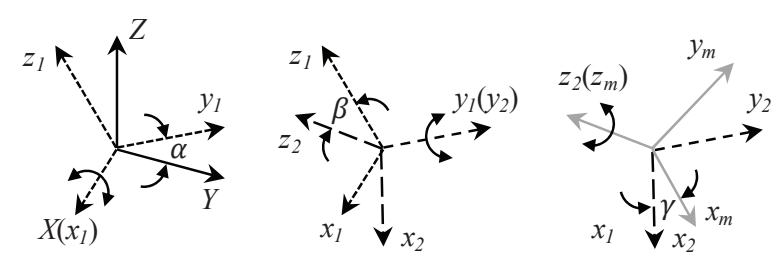

Fig. 4 Coordinate transformation.

\section{3 トルク発生式と回路方程式の連成}

トルク発生式, 回路方程式と運動方程式を連成する ことでモータの駆動特性を考慮する。出力トルク $\tau$ は トルク定数行列 $K_{T}$, 電流ベクトル $I_{a}$, ディテント定数 行列 $K_{D}$, 粘性摩擦係数行列 $D$, 摩擦トルク $\tau_{f}$, を用い て次のように表される。

$$
\begin{aligned}
& \tau=K_{T} I_{a}-K_{D} q-D \dot{q}-\tau_{f} \\
& \tau=\left[\begin{array}{lll}
\tau_{x} & \tau_{y} & \tau_{z}
\end{array}\right]^{T}, \tau_{f}=\left[\begin{array}{lll}
\tau_{f x} & \tau_{f y} & \tau_{f z}
\end{array}\right]^{T} \\
& K_{T}=\operatorname{diag} .\left[K_{T x} K_{T y} K_{T z}\right], K_{D}=\operatorname{diag} .\left[K_{D x} K_{D y} K_{D z}\right] \\
& I_{a}=\left[\begin{array}{lll}
I_{a x} & I_{a y} & I_{a z}
\end{array}\right]^{T}, D=\operatorname{diag} \cdot\left[\begin{array}{lll}
D_{x} & D_{y} & D_{z}
\end{array}\right]
\end{aligned}
$$

ここで，トルク定数とディテント定数は三次元有限要 素法を用いた電磁場解析により得た。

また, 印加電圧ベクトル $V$, コイルの抵抗行列 $R_{c}$, インダクタンス行列 $L$, 逆起電圧定数行列 $K_{B}$ より, 回 路方程式は次のように表される。

$$
\begin{aligned}
& V=R_{c} I_{a}+L \frac{d I_{a}}{d t}+K_{B} \dot{q} \\
& V=\left[\begin{array}{lll}
V_{x} & V_{y} & V_{z}
\end{array}\right]^{T}, R_{c}=\operatorname{diag} \cdot\left[R_{c x} R_{c y} R_{c z}\right] \\
& L=\operatorname{diag} \text {. }\left[\begin{array}{lll}
L_{x} & L_{y} & L_{z}
\end{array}\right], K_{B}=\operatorname{diag} .\left[\begin{array}{lll}
K_{B x} & K_{B y} & K_{B z}
\end{array}\right]
\end{aligned}
$$

\section{4 状態方程式の導出}

式(9)のトルク発生式, 式(10)の回路方程式と式(8)の 運動方程式を連成することでモータの駆動特性を考慮 した状態方程式を導出する。本アクチュエータの状態 方程式は, 次のような三入力三出力の時変モデルとし て状態方程式を導出することができる。

$$
\begin{gathered}
\dot{q}=\left[\begin{array}{c}
\dot{q}_{1} \\
\dot{q}_{2} \\
\dot{q}_{3}
\end{array}\right]=\left[\begin{array}{ccc}
\mathbf{0} & \mathbf{1} & \mathbf{0} \\
-H^{-1} K_{D} & -H^{-1} C_{m} & H^{-1} K_{T} \\
\mathbf{0} & -L^{-1} K_{B} & -L^{-1} R_{c}
\end{array}\right]\left[\begin{array}{c}
q_{1} \\
q_{2} \\
q_{3}
\end{array}\right]+\left[\begin{array}{c}
\mathbf{0} \\
\mathbf{0} \\
L^{-1}
\end{array}\right] V \\
q_{1}=\left[\begin{array}{lll}
\alpha \beta \gamma
\end{array}\right]^{T}, q_{2}=\left[\begin{array}{lll}
\dot{\alpha} \dot{\beta} & \dot{\gamma}
\end{array}\right]^{T}, q_{3}=\left[\begin{array}{ll}
I_{a x} & I_{a y} I_{a z}
\end{array}\right]^{T} \\
C_{m}=C+D
\end{gathered}
$$


Table 2 Analysis condition.

\begin{tabular}{cc}
\hline \hline Number of elements & 1853,988 \\
Number of nodes & 322,571 \\
Number of steps & 2000 \\
Total CPU time & $66.7[\mathrm{~h}]$ \\
\hline \hline
\end{tabular}

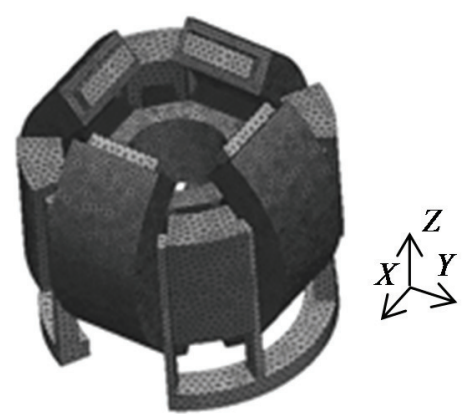

Fig. 5 3-D finite element mesh (except the air).

また, 出力を現在姿勢 $y$ とした出力方程式は次のよ うに表すことができる。

$$
y=\left[\begin{array}{lll}
\boldsymbol{1} & \boldsymbol{0} & 0
\end{array}\right]\left[\begin{array}{l}
q_{1} \\
q_{2} \\
q_{3}
\end{array}\right]
$$

\section{4 数值シミュレーションによる妥当性検証}

導出した状態方程式と出力方程式により表現され るシステムの時間応答と三次元有限要素法を用いた電 磁場解析の動解析結果を比較し, 導出したシステムの 妥当性を検証する。サンプリング周期は $0.1 \mathrm{~ms}$ として, 各軸駆動用コイルに振幅 $5 \mathrm{~V}, 100 \mathrm{~Hz}$ の交流電圧を入 力した。なお，この入力は歩行撮影時の最大振幅を想 定して設定した[14]。また，電磁場解析の解析諸元を Table 2 に，有限要素分割モデルを Fig. 5 に示す。

システムの時間応答と有限要素法を用いた動解析 の解析結果を Fig. 6 に示寸。結果より, 過渡応答時の ピーク值に誤差が発生しているが，定常状態において は両者が良好に一致していることがわかる。 $\mathrm{X} ・ \mathrm{Y}$ 軸 駆動における定常状態での可動子角度の振幅は, 有限 要素法を用いた解析結果において 4.02 度, 導出したシ ステムを用いた計算結果において 3.04 度であり，24\% の誤差があった。次に, Z 軸駆動における定常状態で の可動子角度の振幅は, 有限要素法を用いた解析にお いて 1.07 度, 状態方程式を用いた計算結果において 1.29 度であり，21\%の誤差があった。これらの誤差は 式(9)に示すトルク発生式におけるトルク定数の線形 化による影響であると考えられる。 $\mathrm{X} ・ \mathrm{Y}$ 軸まわりに

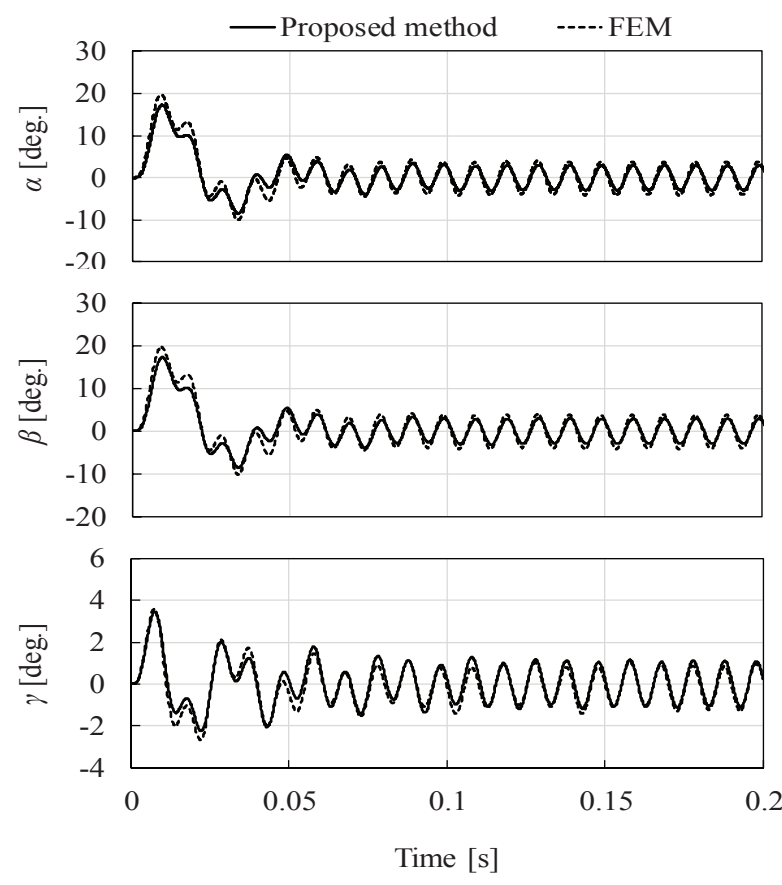

Fig. 6 Analysis results of the proposed method.

おいてトルク定数は最大で約 $30 \%$ の相違がある。また, Z 軸まわりにおいてトルク定数は最大で約 $27 \%$ の相違 があることがわかっている[12]。しかし，有限要素法を 用いた動解析と比較して位相がずれることなく，近似 した結果を得られていることから，導出したシステム の計算結果は妥当であると考えられる。

三次元有限要素法を用いた電磁場解析の動解析で の解析時間は $66.7 \mathrm{~h}$ であり, 1 ステップあたり平均 120 $\mathrm{s}$ を要した。一方で, 導出したシステムによる時間応答 の解析時間は $1.53 \mathrm{~s}$ であり, 1 ステップあたり平均 765 $\mu \mathrm{s}$ を要した。以上の結果より, 導出した状態方程式を 用いて三自由度アクチュエータのシステムを導出する ことで約 157000 分の 1 まで解析時間を短縮できるこ とがわかった。

\section{5 制御系設計と動特性検証}

5.1 積分型コントローラを用いた最適サーボシステム

3.4 節において導出した状態方程式を用いることで 提案したアクチュエータに対して最適制御が適用可能 であることを示すため, 定值の目標值に対する最適サ 一ボシステムを設計する。なお，外乱の影響を除去す るために積分型コントローラを用いた[15]。制御シス テムのブロック線図を Fig. 7 に示す。 
式(11), 式(12)より，未知の外乱 $d(t)$ が加わっている 制御対象に対する拡大偏差システムは偏差 $e(t)$ を用い て次のように表される。

$$
\begin{aligned}
& \left\{\begin{array}{c}
\dot{\widetilde{q}}_{e}(t)=A_{e} \widetilde{q}_{e}(t)+B_{e} \tilde{u}(t) \\
e(t)=C_{e} \widetilde{q}_{e}(t)
\end{array}\right. \\
& A_{e}=\left[\begin{array}{cc}
A & 0 \\
-C & 0
\end{array}\right] \in \mathfrak{R}^{12 \times 12}, B_{e}=\left[\begin{array}{c}
B \\
\boldsymbol{0}
\end{array}\right] \in \mathfrak{R}^{12 \times 3} \\
& C_{e}=\left[\begin{array}{ll}
-C & 0
\end{array}\right] \in \mathfrak{R}^{3 \times 12}
\end{aligned}
$$

ここで, 偏差 $e(t)$ の積分值 $w(t)$ の定常值を $w_{\infty}$ とし, 定 常值 $q_{\infty}, u_{\infty}$ からの変動は次式のように表される。

$$
\begin{gathered}
\widetilde{q}_{e}(t)=\left[\begin{array}{c}
\tilde{q}(t) \\
\widetilde{w}(t)
\end{array}\right]-\left[\begin{array}{l}
q_{\infty} \\
w_{\infty}
\end{array}\right], \tilde{u}(t)=u(t)-u_{\infty} \\
w(t)=\int_{0}^{t} e(t) d t
\end{gathered}
$$

次に, 次式で示される評価関数 $J_{e}$ を最小化するように コントローラを設計する。

$$
\begin{gathered}
J_{e}=\int_{0}^{\infty}\left(\tilde{x}_{e}(t)^{T} Q_{e} \tilde{x}_{e}(t)+\tilde{u}(t)^{T} R_{e} \tilde{u}(t)\right) d t \\
Q_{e}=\left[\begin{array}{cc}
C^{T} Q_{11} C & 0 \\
0 & Q_{22}
\end{array}\right], Q_{11}=Q_{11}^{T}>0 \\
Q_{22}=Q_{22}^{T}>0, R_{e}=R_{e}^{T}>0
\end{gathered}
$$

なお， $Q_{e}$ は状態に対する重み行列， $w_{\infty}$ は操作量に対す る重文行列である。

ここで, コントローラのゲイン $K_{S}$ は最適レギュレー 夕理論より, 次式に示寸リッカチ方程式の正定対象解 $P_{e}$ を用いて求めることができる。

$$
\begin{gathered}
P_{e} A_{e}+A_{e}^{T} P_{e}-P_{e} B_{e} R_{e}^{-1} B_{e}^{T} P_{e}+Q_{e}=0 \\
P_{e}=P_{e}^{T}=\left[\begin{array}{ll}
P_{11} & P_{12} \\
P_{12}^{T} & P_{22}
\end{array}\right]>0 \\
K_{S}=-R_{e}^{-1} B^{T} P_{11} \\
G=-R_{e}^{-1} B^{T} P_{12}
\end{gathered}
$$

このとき, 操作量 $u(t)$ は次のように表すことができる。

$$
\begin{gathered}
u(t)=K_{s} q(t)+G w(t)+F_{a} y_{r e f}(t)+F_{b} q_{0} \\
F_{a}=\left[-K_{S}+2 G P_{22}^{-1} P_{12}^{T} I\right]\left[\begin{array}{ll}
A & B \\
C & 0
\end{array}\right]^{-1}\left[\begin{array}{l}
0 \\
1
\end{array}\right] \\
F_{b}=-2 G P_{22}^{-1} P_{12}^{T}
\end{gathered}
$$

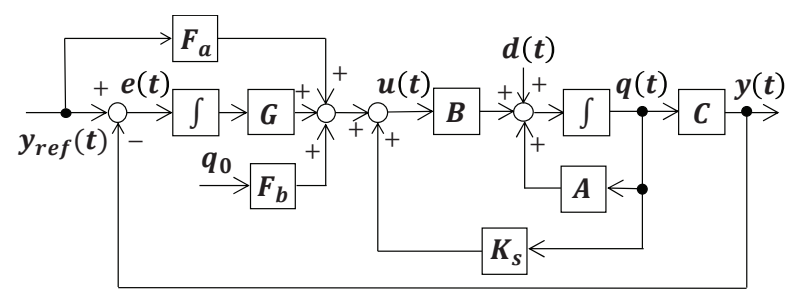

Fig. 7 Block diagram of the control system.

\section{2 動特性検証}

設計した最適サーボシステムの性能を検証するた め, 三軸同時駆動でのステップ応答を求めた。このと き，ステップ状目標值は $0.1 \mathrm{~s}$ において発生させた。ま た，外乱に対するロバスト性を検証するため， $0.3 \mathrm{~s} に$ おいて大きさ 1 のステップ外乱を発生させた。

システムの時間応答を Fig. 8 に示す。加えて, 応答 時の操作量を Fig. 9 に示す。まず Fig. 8 より, 可動子 がステップ状目標值に対して定常偏差なく良好に追従 していることがわかる。また，ステップ状外乱を加え た際には目標值に対して誤差が発生したが，即座に対 応し，外乱の影響を抑制していることがわかる。次に Fig. 9 より，ステップ状目標值と外乱が与えられた際 に操作量が適時加えられていることから，アクチュエ 一タが適切に応答していることがわかる。

以上の結果から，導出した状態方程式を用いること で最適サーボシステムを設計することが可能であるこ とを示した。

\section{6 結言}

本稿では, 動特性の計算に要する時間の短縮と最適 制御系設計を目的として，振れ補正用三自由度アクチ ユエータの動的モデリング手法を提案した。まず，ア クチュエータの基本構造と駆動原理を示した。次に, ラグランジュ法をもとに運動方程式を導出した。また, モータダイナミクスと運動方程式を連成し, 状態方程 式を求めた。そして, 導出したシステムと三次元有限 要素法を用いた動解析の解析結果を比較し，両者が良 好に一致すること，導出したシステムを用いることで 大幅に解析時間を短縮できることを示した。さらに, 導出したシステムを用いて動特性を検証するため，積 分型コントローラを用いた最適サーボシステムを設計 し，導出した状態方程式を用いることで最適制御を実 装可能であることを示した。今後は, 試作機と導出し たシステムの挙動を比較し，妥当性を検証する。 

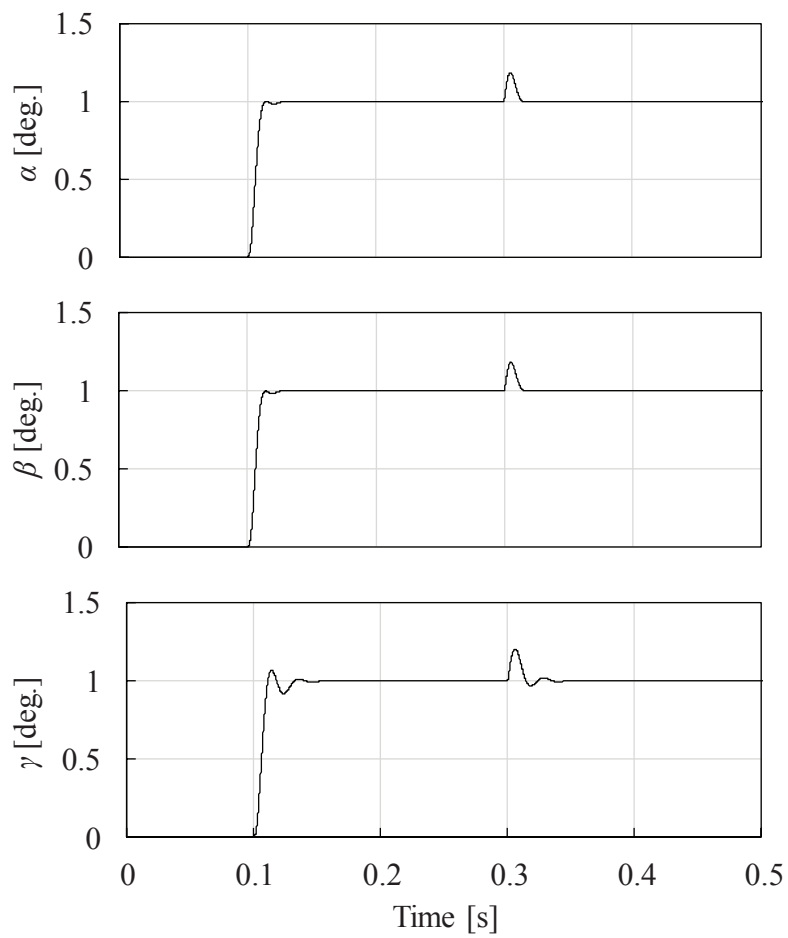

Fig. 8 Step response of the control system.

\section{参考文献}

[1] W. G Aguilar, and C. Angulo, Real-time video stabilization without phantom movements for micro aerial vehicles, EURASIP J. on Image and Video Processing, vol. 46, Dec. 2014.

[2] R. Kura zume, and S. Hirose, Development of image stabilization for remote operation of walking robots, Proc. of the 2000 IEEE Inter. Conf. on Robotics and Automat., pp. 1856-1861, San Francisco, CA, Apr. 2000.

[3] S.-C. Hsu, S.-F. Liang, K.-W. Fan, and C.-T. Lin, A Robust In-Car Digital Image Stabilization Technique, IEEE Trans. on Systems, Man, and Cybernetics, Part C: Applications and Reviews, vol. 37, no. 2, pp. 234-247, Mar. 2007.

[4] 新谷大, 三谷芳史, 真島拓士，柴谷一弘，系原俊夫， レンズユニットスイング方式手振れ補正ユニットの 開発，KONICA MINOLTA Tech. Rep., Vol. 3, pp. 149$152,2006$.

[5] W. Wang, J. Wang, G. W. Jewel and D. Howe, Design and Control of a Novel Spherical Permanent Magnet Actuator With Three Degrees of Freedom, IEEE/ASME Trans. on Mechatron., Vol. 8, No. 4, pp. 457-468, 2003.

[6] K. Kahlen, I. Voss, C. Priebe and R. De Doncker, Torque Control of a Spherical Machine With Variable Pole Pitch, IEEE Trans. on Power Electron., Vol. 19, No. 6, pp. 16281634, 2004.

[7] L. Yan, I-M. Chen, C. K. Lim, G. Yang, W. Lin and K.-M. Lee, Design and Analysis of a Permanent Magnet Spherical Actuator, IEEE/ASME Trans. Mechatron., Vol. 13, No. 2, pp. 239-248, 2008.
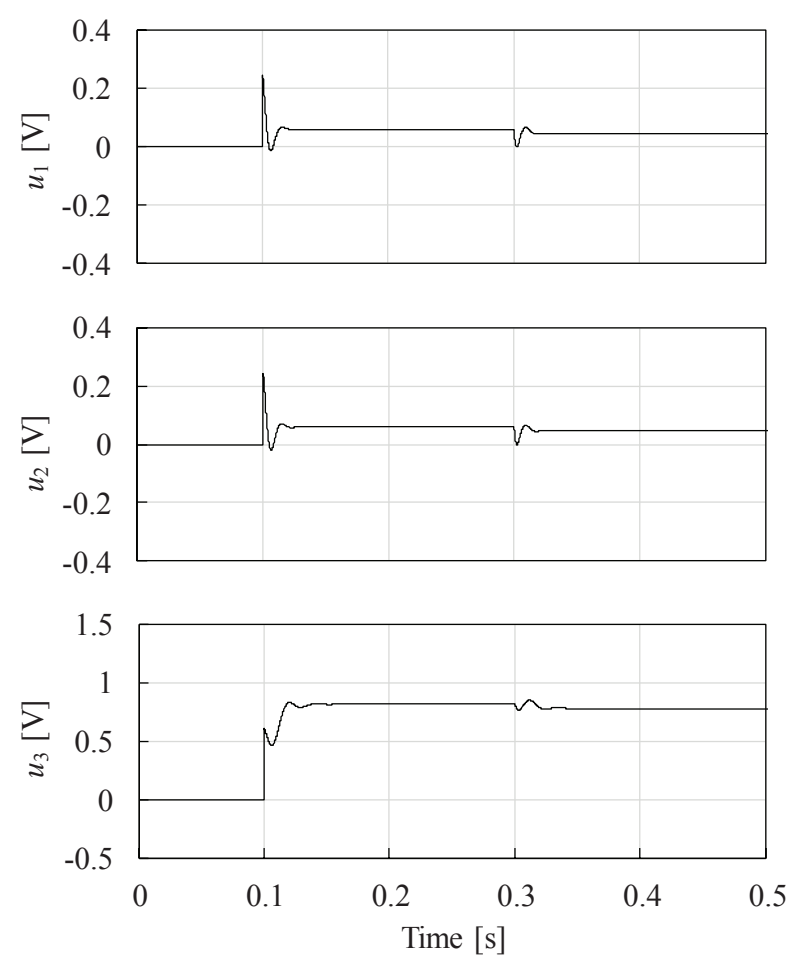

Fig. 9 Control input of the control system.

[8] H. J. Lee, H. J. Park, G. H. Ryu, S.Y. Oh and J. Lee, Performance Improvement of Operating Three-Degreeof-Freedom Spherical Permanent-Magnet Motor, IEEE Trans. Magn., Vol. 48, No. 11, pp. 4654-4657, 2012.

[9] 佐々木亮, 五福明夫, 矢野智昭, 柴田光宣, 切頂八面 体と正十二面体にもとづく球面モー夕の開発，日本 AEM 学会誌, Vol. 21, No. 2, pp. 184-189, 2013.

[10] B. van Ninhuijs, J. W. Jansen, B. L. J. Gysen and E. A. Lomonova, Topology Comparison of Slotless Permanent Magnet Semispherical Actuators, IEEE Trans. Magn., Vol. 50, No. 11, 8206104, 2014.

[11］西浦悠介，平田勝弘，大矢桂資，堺谷洋，新口昇，遺 伝的アルゴリズムを用いた三自由度球面アクチュエ 一夕の磁極配置最適化, 日本 AEM 学会誌, Vol.23, No.2, pp. 332-337, 2015.

[12] 部矢明, 平田勝弘, 吉元崇倫, 太田智浩, 高速動作可 能な振れ補正用 3 自由度アクチュエータの提案, リ ニアドライブ研究会, 電気学会, LD17-19, pp. 107112, 大阪，2017 年 1 月

[13] A. Heya, K. Hirata, N. Niguchi, T. Yoshimoto, T. Ota, Dynamic Analysis of High-Speed Three-Degree-ofFreedom Electromagnetic Actuator for Image Stabilization, IEEE Trans. Magn., Vol. 53, No. 11, 2706942, 2017.

[14］大嶋昭, 映像情報機器の脆弱性改善のための要素技 術に関する研究, 早稲田大学博士論文, 2006.

[15] 池田雅夫, 須田信英, 積分型最適サーボ系の構成, 計 測自動制御学会， Vol. 24, No. 1, pp. 40-46, 1988 